\title{
Ultrasonic-Assisted Extraction of Natural Yellow Pigment from Physalis pubescens L. and Its Antioxidant Activities
}

\author{
Haitang Wang, ${ }^{1}$ Lin Shi, ${ }^{1}$ Xiaoyu Yang, ${ }^{1}$ Rui Hong $\mathbb{D D}^{2}$ and Liang Li $\mathbb{i D}^{1}$ \\ ${ }^{1}$ College of Food Science, Northeast Agricultural University, Harbin 150030, China \\ ${ }^{2}$ Department of Academic Theory Research, Northeast Agricultural University, Harbin 150030, China \\ Correspondence should be addressed to Rui Hong; hongrui3610@163.com and Liang Li; liliangneau@163.com
}

Received 17 January 2018; Revised 12 June 2018; Accepted 19 June 2018; Published 24 July 2018

Academic Editor: Mohammednoor Altarawneh

Copyright (c) 2018 Haitang Wang et al. This is an open access article distributed under the Creative Commons Attribution License, which permits unrestricted use, distribution, and reproduction in any medium, provided the original work is properly cited.

\begin{abstract}
Physalis pubescens L. is rich in natural pigments but has not yet been fully utilized. Ultrasound-assisted extraction of yellow pigment from Physalis pubescens L. was investigated by response surface methodology in this study. Optimal parameters were ultrasonic power of $29.21 \%$, ultrasonic time of $14.41 \mathrm{~min}$, and ultrasonic interval time of $10.55 \mathrm{~s}$. The yield was $0.193 \%$ under optimal parameters. FRAP, ABTS, and superoxide radical scavenging activity of the yellow pigment were $6.11 \pm 0.22 \mathrm{mmol} / \mathrm{g}$, $2.80 \pm 0.27 \mathrm{mmol} / \mathrm{g}$, and $57281.5 \pm 2749.5 \mathrm{U} / \mathrm{g}$, respectively. The results showed that the yield of yellow pigment could be improved by ultrasonic-assisted extraction and the yellow pigment extracted by ultrasound had antioxidant activity.
\end{abstract}

\section{Introduction}

Physalis pubescens L. is a plant cultivated mainly in Hulunbeier League in Inner Mongolia and Greater Hinggan mountains in Heilongjiang Province, China [1]. Physalis pubescens $\mathrm{L}$. is a kind of nutritious and healthy fruit, which contains good amounts of vitamin $\mathrm{C}$, niacin, carotenoids, minerals, antimicrobial molecules, and bioactive withanolides, and it could be a good potential source of essential amino acids [2-4]. Physalis pubescens L. has been used as a traditional folk medicine to treat sore throat, cough, urethritis, hematuria, and orchitis [5]. So Physalis pubescens L. has a nutrient, medicine, and economic importance in many countries.

The fruits of Physalis are consumed either fresh or processed, mainly for jam, canning, or preserves [6], but less attention is paid to the rich natural yellow pigment resources in fruit. Natural yellow pigment is important for food industry, because natural pigment is much safer and healthier [7], so the demand for natural pigments is growing. Ultrasound-assisted extraction could increase the yield of extracted components, achieving reduction in extraction time and higher processing throughput [8]. Now ultrasonic-assisted extraction has been successfully applied with extraction of anthocyanins, carotenoids, phenolic compounds, and flavonoids [9-12]. Ultrasonic-assisted extraction has been applied with extraction of Pueraria isoflavonoids, and the ultrasonic-assisted extraction condition was optimized by response surface methodology (RSM), for the maximum recovery of isoflavonoids with high cytoprotective effect [13]. Ultrasonic-assisted extraction of phenolic compounds from fresh olives was studied to increase the yield of phenolic compounds [14]. The anthocyanins and other phenolic compounds from purple eggplant peels and pulps were extracted by ultrasonicassisted extraction, and these results indicated that suitable ultrasonic pretreatment can reduce the extraction time with high yield of phenolic compounds [15]. Ultrasonicassisted extraction has been applied with extraction of phenolics and antioxidant compounds from rhizomes of Rheum moorcroftianum using response surface methodology, and the results indicate that the design to optimize the extraction of polyphenolic compounds is critical for precise quantification of antioxidant phenolics [16]. Ultrasonicassisted extraction could be applied to extract the target compounds in complex plant samples [17]. 
In this paper, Physalis pubescens L. grown in China was chosen as raw material; ultrasound-assisted extraction of yellow pigment of Physalis pubescens L and antioxidant activity of yellow pigment were investigated. The purpose of this research was to study an efficient extraction method of natural yellow pigment of Physalis pubescens L. The result could provide a kind of natural yellow pigment with excellent function to the food industry, which would enhance the economic and nutritional value of Physalis pubescens L.

\section{Materials and Methods}

2.1. Materials. The raw Physalis pubescens L. was purchased in a local market, rutin was provided by National Institutes for Food and Drug Control (Beijing, China), and ethanol was purchased from Tianli Chemical Reagent Co. (Tianjin, China). The superoxide radical scavenging assay kits were purchased from Nanjing Jiancheng Bioengineering Institute (Jiangsu, China). Ferric-reducing antioxidant power (FRAP) assay kit and the total antioxidant capacity (ABTS method) assay kit were purchased from Beyotime Institute of Biotechnology (Shanghai, China).

2.2. Extraction of Yellow Pigment. Physalis pubescens L. juice was frozen using a FD5 freeze dryer (Sim International Co. Ltd., Beijing, China). Freeze-dried Physalis pubescens L. powder was dissolved in $75 \%$ ethanol by solid-liquid ratio of $1: 12$. The ultrasound-assisted extraction was performed on an ultrasonic homogenizer (JY92-II, Ningbo Scientz Biotechnology Co., Ltd., China).

2.3. Determination of Yellow Pigment. Yellow pigment was determined by spectrophotometry based on the modified method by Jia and $\mathrm{Wu}[18,19]$. The total amount of reaction system was $25 \mathrm{~mL}$. $5 \mathrm{~mL}$ extract was diluted to $10 \mathrm{~mL}$ with $75 \%$ ethanol and then $0.75 \mathrm{~mL} \mathrm{NaNO}_{2}(5 \% \mathrm{~W} / \mathrm{V})$ was added. After 5 minutes, $0.75 \mathrm{~mL} \mathrm{Al}\left(\mathrm{NO}_{3}\right)_{3}(10 \% \mathrm{~W} / \mathrm{V})$ was added into the solution and the mixture was mixed well. After 6 minutes, $5 \mathrm{~mL}$ of sodium hydroxide was added into mixture. The mixture was placed at room temperature for 10 minutes. The absorbance was measured by a UV-1800 spectrophotometer (Pgeneral Instrument (Beijing) Co. Ltd., Beijing, China) at $510 \mathrm{~nm}$. Yellow pigment was determined using rutin calibration curves $\left(y=6.412 x+0.003 ; R^{2}=0.998\right.$, where $y$ is the absorbance and $x$ is the rutin equivalent concentration $(\mathrm{mg} / \mathrm{ml})$ ).

Yield $(\%)=m_{1} / m_{2} \times 100 \%$, where $m_{1}$ is the weight of the extracted yellow pigment and $m_{2}$ is the weight of the sample.

2.4. Single-Factor Experiments. Factors and levels of singlefactor experiment design are shown in Table 1. The three single factors that affected the extraction of yellow pigment were ultrasonic power, ultrasonic time, and ultrasonic interval time.

2.5. Response Surface Design. Response surface design was applied to find the optimal yield of yellow pigment. The optimization of extraction parameters was designed based on the single-factor experiments, and the ranges of the
TABLE 1: Factors and levels of single-factor experiments.

\begin{tabular}{cccc}
\hline & $\begin{array}{c}\text { Ultrasonic } \\
\text { power }(\%)\end{array}$ & $\begin{array}{c}\text { Ultrasonic } \\
\text { time }(\mathrm{min})\end{array}$ & $\begin{array}{c}\text { Ultrasonic } \\
\text { interval time }\end{array}$ \\
\hline 1 & $15 \%(97.5 \mathrm{~W})$ & 3 & $5 \mathrm{~s}(5 \mathrm{~s} \text { on, } 5 \mathrm{~s} \mathrm{off})^{*}$ \\
2 & $30 \%(195 \mathrm{~W})$ & 6 & $10 \mathrm{~s}(10 \mathrm{~s}$ on, $10 \mathrm{~s}$ off $)$ \\
3 & $45 \%(292.5 \mathrm{~W})$ & 9 & $15 \mathrm{~s}(15 \mathrm{~s}$ on, $15 \mathrm{~s}$ off $)$ \\
4 & $60 \%(390 \mathrm{~W})$ & 12 & - \\
5 & $75 \%(487.5 \mathrm{~W})$ & 15 & - \\
\hline
\end{tabular}

Note. Ultrasonic interval time $5 \mathrm{~s}$ means that each cycle is $5 \mathrm{~s}$ on and $5 \mathrm{~s}$ off at corresponding ultrasonic power.

TABle 2: Response surface design.

\begin{tabular}{|c|c|c|c|}
\hline & $\begin{array}{c}\text { Ultrasonic } \\
\text { power (\%) } \\
\text { A }\end{array}$ & $\begin{array}{c}\text { Ultrasonic } \\
\text { time (min) } \\
\text { B }\end{array}$ & $\begin{array}{c}\text { Ultrasonic } \\
\text { interval time } \\
\text { C }\end{array}$ \\
\hline 1 & 35 & 18 & $15 \mathrm{~s}$ (on $15 \mathrm{~s}$, off $15 \mathrm{~s})$ \\
\hline 0 & 30 & 15 & $10 \mathrm{~s}$ (on $10 \mathrm{~s}$, off $10 \mathrm{~s}$ ) \\
\hline-1 & 25 & 12 & $5 \mathrm{~s}$ ( on $5 \mathrm{~s}$, off $5 \mathrm{~s})$ \\
\hline
\end{tabular}

variables investigated are displayed in Table 2: ultrasonic power $25 \%-35 \%$, ultrasonic time $12-18 \mathrm{~min}$, and ultrasonic interval time ( $5 \mathrm{~s}, 10 \mathrm{~s}$, and $15 \mathrm{~s})$.

2.6. ABTS (2,2'-Azino-bis(3-ethylbenzothiazoline-6-sulfonic Acid) Activity. ABTS was prepared by using the ABTS assay kit (Beyotime Institute of Biotechnology (Shanghai, China)). The prepared ABTS solution was kept at room temperature in dark for $12-16 \mathrm{~h}$. The prepared ABTS solution was then diluted with $10 \mathrm{mM}$ phosphate buffer (PBS, $\mathrm{pH} 7.0)$ to obtain an absorbance of $0.70 \pm 0.05$ at $734 \mathrm{~nm}$ [20]. The reaction was initiated with addition of $10 \mu \mathrm{L}$ sample solution into $200 \mu \mathrm{L}$ ABTS mixture. The absorbance at $734 \mathrm{~nm}$ was recorded after $5 \mathrm{~min}$ at room temperature. The standard curve was constructed using Trolox standard solution [21]. Total antioxidant capacity $(\mathrm{mmol} / \mathrm{g})=\mathrm{C}_{1} / \mathrm{C}_{2}$, where $C_{1}$ is the concentration of the Trolox standard solution when inhibition rate of the sample is equal to the inhibition rate of Trolox standard solution $(\mathrm{mmol} / \mathrm{L})$ and $\mathrm{C}_{2}$ is the concentration of the sample $(\mathrm{mg} / \mathrm{ml})$.

2.7. Superoxide Radical Scavenging Activity. Superoxide radical scavenging activity was determined by using an assay kit (Nanjing Jiancheng Bioengineering Institute, Nanjing, China) according to the manufacturer's instructions [22]. The absorbance of reaction solution was measured at $550 \mathrm{~nm}$. Superoxide radical scavenging activity is expressed as $\mathrm{U} / \mathrm{g}$.

2.8. FRAP (Ferric-Reducing Antioxidant Power) Assay. FRAP was measured by commercial kit of Beyotime Institute of Biotechnology (Jiangsu, China). $5 \mu \mathrm{L}$ sample solution was added into $180 \mu \mathrm{L}$ FRAP working solution at room temperature, and the mixture was incubated for $5 \mathrm{~min}$ at $37^{\circ} \mathrm{C}$. The absorbance of the mixture was measured at $593 \mathrm{~nm}$. The PBS was used as blank control. The standard curve was constructed using $\mathrm{FeSO}_{4} \cdot 7 \mathrm{H}_{2} \mathrm{O}$ solution [23]. 


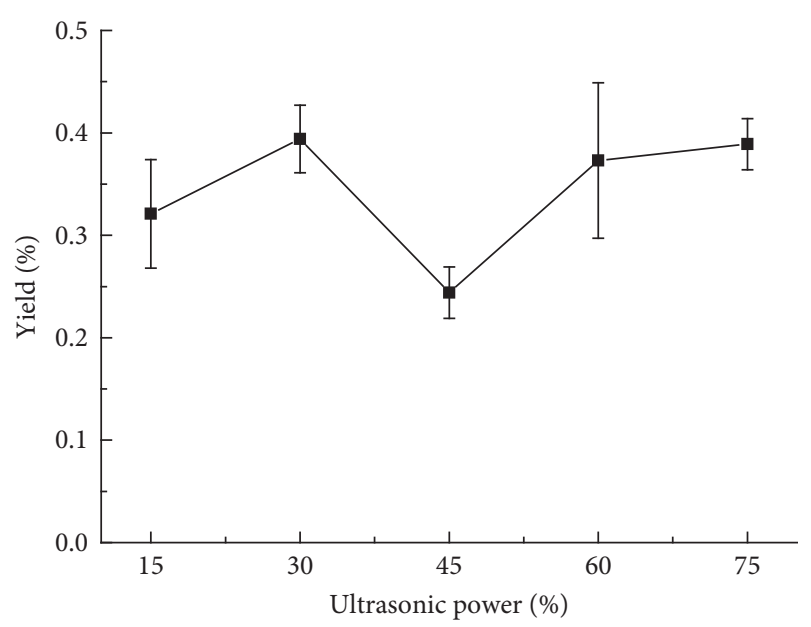

FIGURE 1: Influence of ultrasonic power on yield of yellow pigment.

The total antioxidant capacity $(\mathrm{mmol} / \mathrm{g})=C_{1} / C_{2}$, where $C_{1}$ is the concentration of the $\mathrm{FeSO}_{4}$ solution when the absorbance of the sample is equal to the absorbance of the $\mathrm{FeSO}_{4}$ solution $(\mathrm{mmol} / \mathrm{L})$ and $C_{2}$ is the concentration of the sample $(\mathrm{mg} / \mathrm{mL})$.

2.9. Statistical Analysis. All the data were analyzed using SPSS 17 software (SPSS Inc., Chicago, IL). The results were expressed as mean $\pm \mathrm{SD}$.

\section{Results and Discussion}

3.1. Influence of Ultrasonic Power on Yield of Yellow Pigment. The effect of ultrasonic power on yield of yellow pigment was investigated. Ultrasonic power was taken at $15 \%(97.5 \mathrm{~W})$, $30 \%(195 \mathrm{~W}), 45 \% \quad(292.5 \mathrm{~W}), 60 \% \quad(390 \mathrm{~W})$, and $75 \%$ (487.5 W), respectively, while other extraction variables were as follows: the solid-liquid ratio of $1: 12$ and ethanol concentration of $75 \%$. The results are shown in Figure 1. It could be seen that the yield was the highest when the ultrasonic power was $30 \%(195 \mathrm{~W})$ and the yield value was $0.394 \pm$ $0.033 \%$ (Figure 1). The lowest yield among the five points appeared when the ultrasonic power was $45 \%(270 \mathrm{~W})$ and the yield value was $0.244 \pm 0.025 \%$. When the power was increased from $45 \%$ to $75 \%$, the yield rose again, but never more than the maximum value. The materials swell and the pores enlarge as a result of the microjet and the violent shock wave produced by the ultrasonic wave, which enhanced the extraction yield. However, the number of cavities might increase sharply above $195 \mathrm{~W}$ of ultrasonic power, which negatively influenced the efficiency of the ultrasound energy transmitted into the medium, and reduce the extraction yield [24].

3.2. Effect of Ultrasonic Interval Time on Yield of Yellow Pigment. Ultrasonic interval time $(5 \mathrm{~s}, 10 \mathrm{~s}$, and $15 \mathrm{~s})$ was investigated at the solid-liquid ratio of $1: 12$ and ethanol concentration of $75 \%$. The results are shown in Figure 2. The results showed that the yield of yellow pigment was the highest when the ultrasonic interval time was $10 \mathrm{~s}$ and the yield value was $0.454 \pm 0.057 \%$. The yield was lower

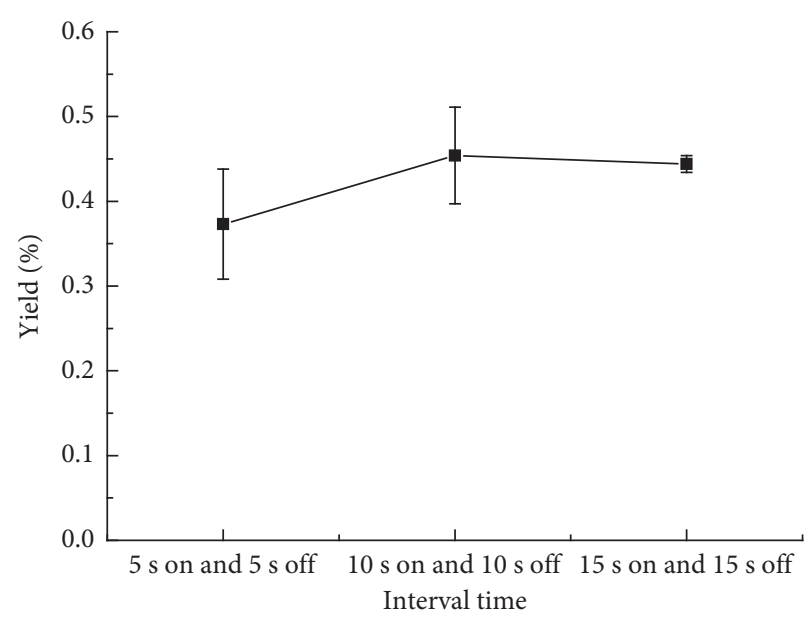

FIGURE 2: Influence of ultrasonic interval time on yield of yellow pigment.

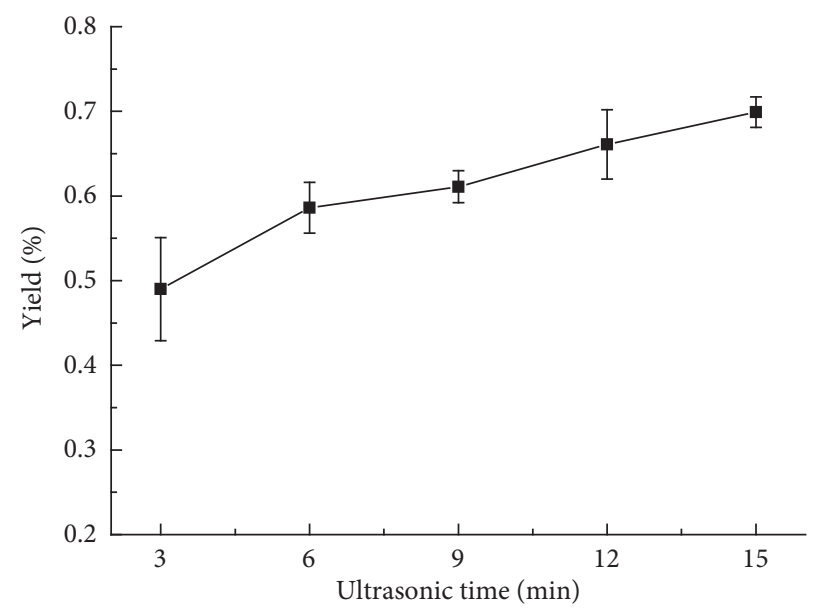

FIGURE 3: Influence of ultrasonic time on yield of yellow pigment.

TABLE 3: Results of response surface experiment.

\begin{tabular}{lcccc}
\hline Run & $\begin{array}{c}\text { Ultrasonic } \\
\text { power (\%) }\end{array}$ & $\begin{array}{c}\text { Ultrasonic } \\
\text { time (min) }\end{array}$ & $\begin{array}{c}\text { Ultrasonic } \\
\text { interval time }\end{array}$ & $\begin{array}{c}\text { Yield } \\
(\%)\end{array}$ \\
\hline 1 & A & B & C & \\
2 & -1 & -1 & 0 & 0.177 \\
3 & 1 & -1 & 0 & 0.116 \\
4 & -1 & 1 & 0 & 0.110 \\
5 & 1 & 1 & 0 & 0.094 \\
6 & -1 & 0 & -1 & 0.111 \\
7 & 1 & 0 & -1 & 0.101 \\
8 & -1 & 0 & 1 & 0.123 \\
9 & 1 & 0 & 1 & 0.132 \\
10 & 0 & -1 & -1 & 0.116 \\
11 & 0 & 1 & -1 & 0.111 \\
12 & 0 & -1 & 1 & 0.126 \\
13 & 0 & 1 & 1 & 0.136 \\
14 & 0 & 0 & 0 & 0.171 \\
15 & 0 & 0 & 0 & 0.201 \\
16 & 0 & 0 & 0 & 0.192 \\
17 & 0 & 0 & 0 & 0.192 \\
\hline
\end{tabular}



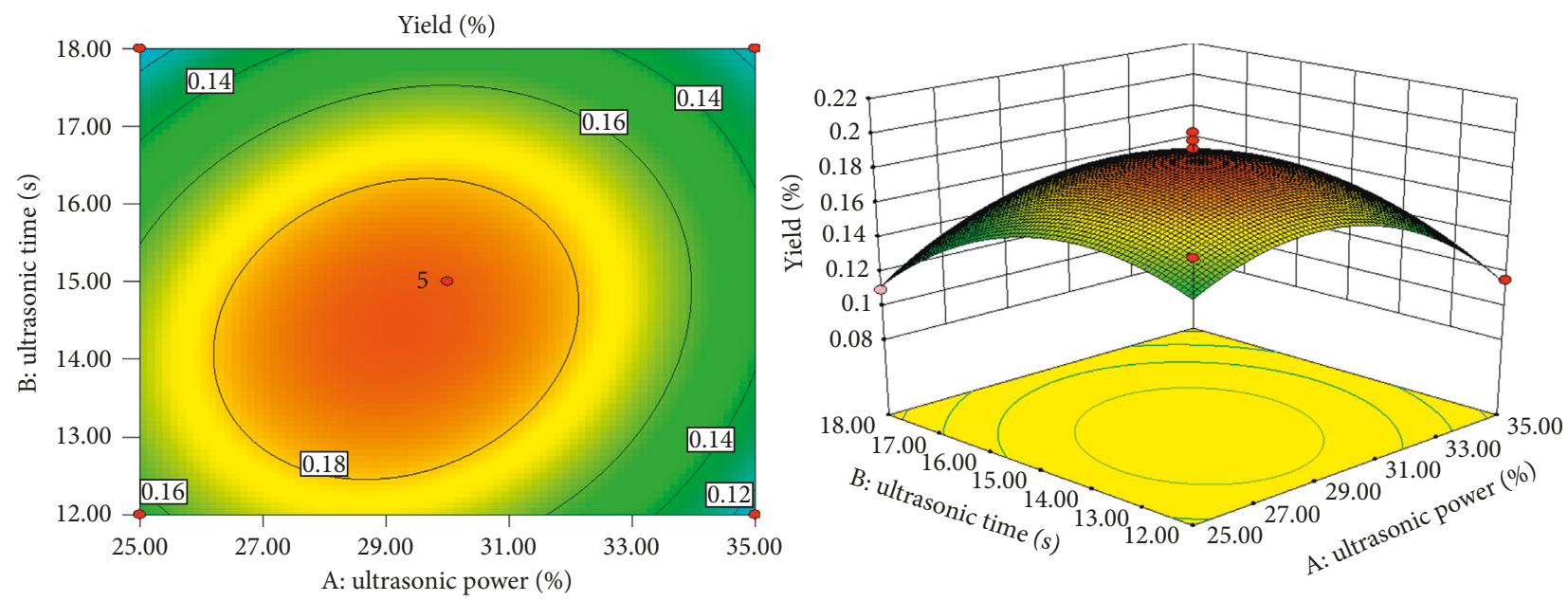

(a)
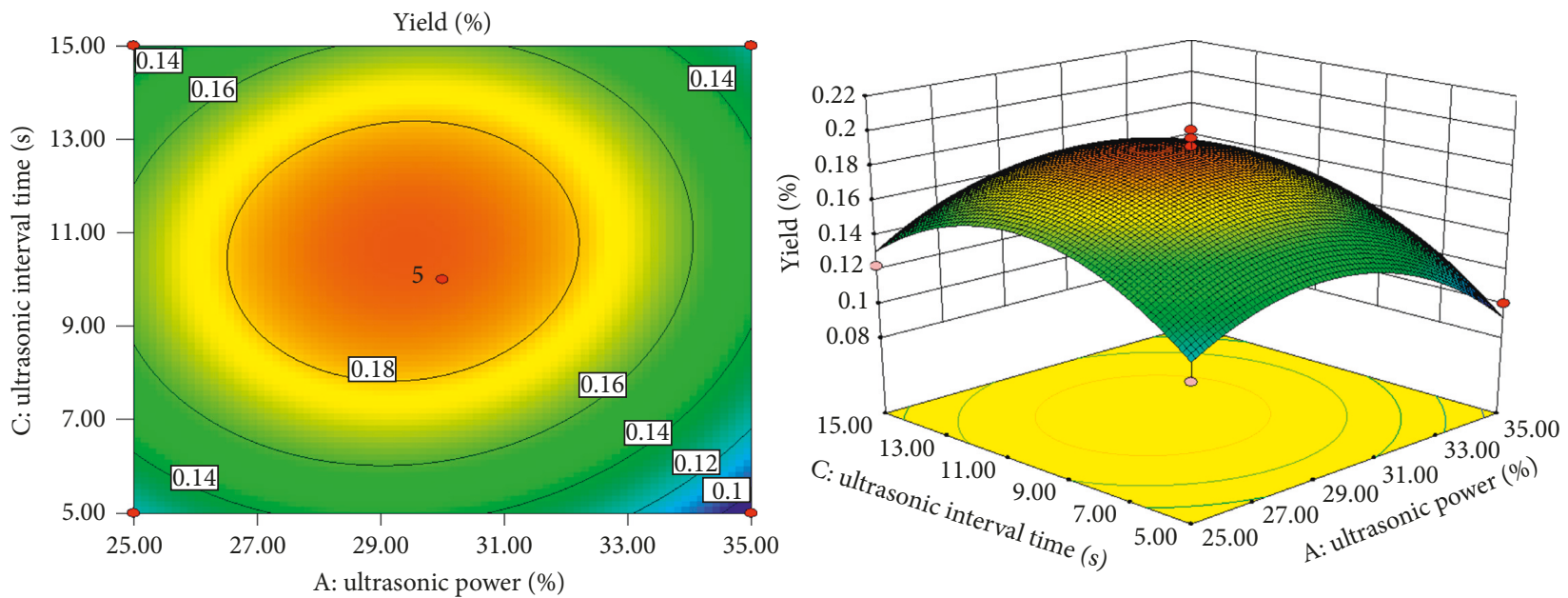

(b)
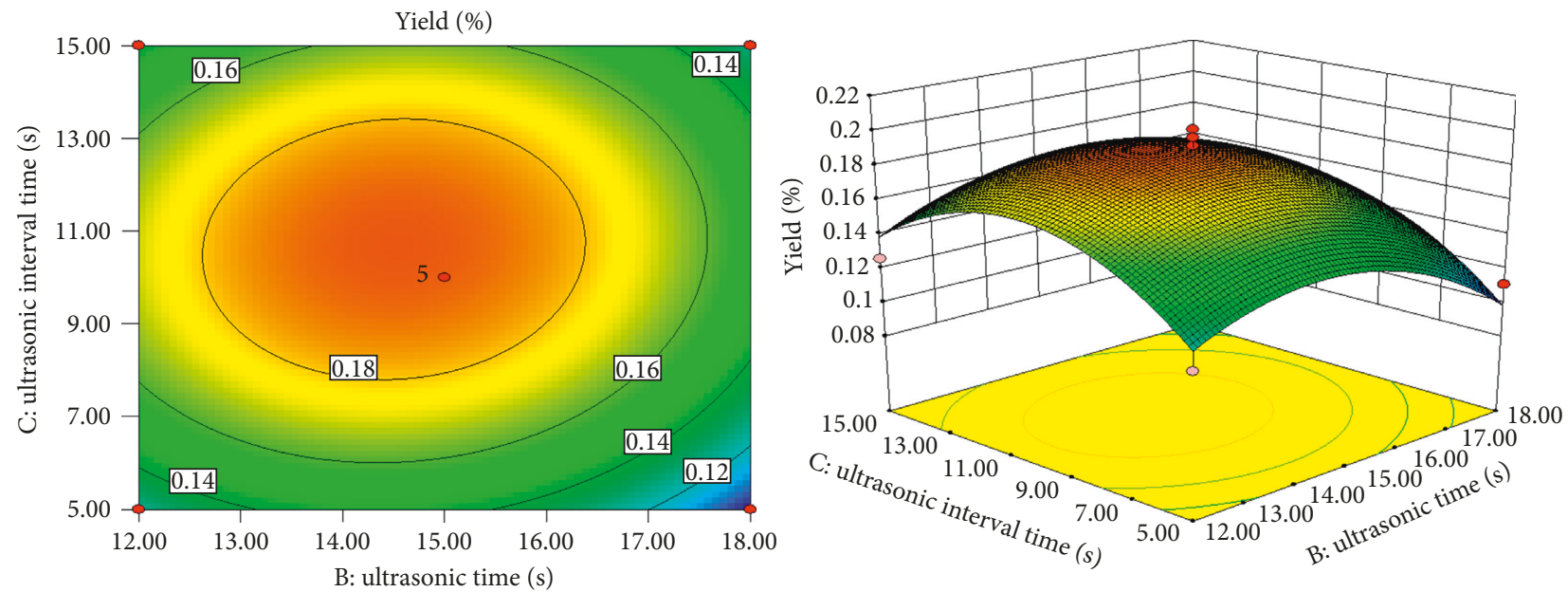

(c)

FIgURE 4: Response surface and contour plot of ultrasonic-assisted extraction on yield of yellow pigment.

at ultrasonic interval time of $5 \mathrm{~s}$ and $15 \mathrm{~s}$ (Figure 2). It might be that ultrasound facilitated the natural yellow pigment release to the exterior solvent and most of the natural yellow pigment released [25].
3.3. Effect of Ultrasonic Time on Yield of Yellow Pigment. Ultrasonic time ( $3 \mathrm{~min}, 6 \mathrm{~min}, 9 \mathrm{~min}, 12 \mathrm{~min}$, and $15 \mathrm{~min}$ ) was investigated at the solid-liquid ratio of $1: 12$ and ethanol concentration of $75 \%$. The results are shown in Figure 3. 
It could be seen from Figure 3 that the yield increased with increase in ultrasonic time. The highest yield appeared when the ultrasound time was $15 \mathrm{~min}$ and the yield value was $0.699 \pm 0.018 \%$. These results could be explained as the increase of extraction time led to the increase of material cell disruption and speeded up both the release and diffusion into water [26].

3.4. Response Surface Methodology. Ultrasonic power, ultrasonic time, and ultrasonic interval time were used as the dependent variables, and the yield of yellow pigment was taken as the response value. The response surface analyses were carried out by the design expert software. The results are listed in Table 3. According to a regression analysis of the experimental data, the yield could be explained by the following equation:

$$
\begin{aligned}
Y= & 0.19-9.796 E-003 * A-0.011 * B+9.796 E-003 * C \\
& +0.011 * A * B+4.971 E-003 * A * C+3.509 E \\
& -003 * B * C-0.036 * A^{2}-0.030 * B^{2}-0.038 * C^{2},
\end{aligned}
$$

where $Y$ represents the yield of yellow pigment; $A, B$, and $C$ are the ultrasonic power, ultrasonic time, and ultrasonic interval time, respectively. $P$ values of the model less than 0.05 indicate that the model terms were significant and lack of fit was not significant $(P>0.05)$.

The response surface plots shown in Figure 4 demonstrated the changes in the yield of yellow pigment with the interaction effects of the three variables. All the three surfaces were upper convex, with a maximum point in the center of the experimental domain. This result demonstrated that the ranges of factors were chosen properly [27]. The yield of yellow pigment increased with increasing ultrasonic power from $25 \%$ to $29.21 \%$ and then decreased slightly above $29.21 \%$. The yield of yellow pigment efficiency increased with the ultrasonic time increasing from about 12 to $14.41 \mathrm{~min}$, but decreased after the optimum value (14.41 $\mathrm{min})$. The possible reason to explain this result was that the ultrasound waves generated cavitation and mechanical forces and improved the mass transfer by disrupting the cell walls. On the other hand, extreme high ultrasonic power and time could decompose target compounds $[17,26]$.

3.5. Antioxidant Activity. The antioxidant activity of yellow pigment was studied by measuring the FRAP assay, superoxide radical scavenging activity $\left(\mathrm{O}_{2}^{-}\right)$, and ABTS assay. The results are shown in Table 4. In Table 4, the FRAP value of the yellow pigment was $6.11 \pm 0.22 \mathrm{mmol} / \mathrm{g}$ and this result was higher than the FRAP value of the $50 \%$ of ethanolic corn silk extracts $(0.44 \pm 0.08 \mathrm{mg} / \mathrm{g})$ [28] and the FRAP value of kidney bean $(99.36 \pm 1.26 \mu \mathrm{mol} / \mathrm{g})$ [29]. The activity of inhibiting $\mathrm{O}_{2}^{-}$free radical was $57281.5 \pm 2749.5 \mathrm{U} / \mathrm{g}$, which was much larger than $\mathrm{O}^{2-}$ inhibition activities of Arabidopsis seedlings $(<1000 \mathrm{U} / \mathrm{g})$ [22]. The ABTS value of the yellow pigment was $2.80 \pm 0.27 \mathrm{mmol} / \mathrm{g}$ and this result was
TABLE 4: Antioxidant activity of yellow pigment.

\begin{tabular}{lccc}
\hline $\begin{array}{l}\text { Antioxidant } \\
\text { activity }\end{array}$ & $\begin{array}{c}\text { FRAP } \\
(\mathrm{mmol} / \mathrm{g})\end{array}$ & $\begin{array}{c}\text { ABTS } \\
(\mathrm{mmol} / \mathrm{g})\end{array}$ & $\mathrm{O}_{2}{ }^{-}(\mathrm{U} / \mathrm{g})$ \\
\hline Yellow pigment & $6.11 \pm 0.22$ & $2.80 \pm 0.27$ & $57281.5 \pm 2749.5$ \\
\hline
\end{tabular}

better than that of the bioactive compounds from palmpressed fiber by ultrasound-assisted extraction, which inhibited the ABTS radical activity of $0.346 \mathrm{mmol} / \mathrm{g}$ [30]. Yellow pigment exerted significantly higher ABTS-radical scavenging activity as compared to I. galbana (0.086 \pm $0.006 \mathrm{mmol} / \mathrm{g})$ and C. calcitrans $(0.068 \pm 0.003 \mathrm{mmol} / \mathrm{g})$ [31] The results showed that the yellow pigment extracted from Physalis pubescens $\mathrm{L}$. had a good antioxidant activity, but the relationship between antioxidant activity and yellow pigment concentration and the mechanism of action needed to be further explored.

\section{Conclusions}

It could be proved that the method of ultrasonic-assisted extraction of yellow pigment from Physalis pubescens L. was indeed effective and feasible in this study. The optimal process parameters solved by the regression equation were ultrasonic power of $29.21 \%$, ultrasonic time of $14.41 \mathrm{~min}$, and ultrasonic interval time of $10.55 \mathrm{~s}$. The yield was $0.193 \%$ under optimal process parameters. Furthermore, the results showed that the crude yellow pigment from Physalis pubescens $\mathrm{L}$. had antioxidant activity. The results provided evidence for further development and utilization of yellow pigment of Physalis pubescens $\mathrm{L}$.

\section{Data Availability}

The data used to support the findings of this study are included within the article.

\section{Conflicts of Interest}

The authors declare that there are no conflicts of interest regarding the publication of this paper.

\section{Acknowledgments}

This study was supported by the Special Fund Project of Harbin Science and Technology Innovation Talents of Harbin Science and Technology Bureau (no. 2015RQQXJ032).

\section{References}

[1] L. Ji, Y. Yuan, Z. Ma et al., "Induction of quinone reductase (QR) by withanolides isolated from Physalis pubescens L. (Solanaceae)," Steroids, vol. 78, no. 9, pp. 860-865, 2013.

[2] L. X. Chen, G. Y. Xia, H. He, J. Huang, F. Qiu, and X. L. Zi, "New withanolides with TRAIL-sensitizing effect from Physalis pubescens L.," RSC Advances, vol. 6, no. 58, pp. 52925-52936, 2016.

[3] A. F. Elsheikha, M. S. Zaki, A. A. Bakr, M. M. Elhabashy, and D. Montet, "Biochemical and sensory quality of physalis (Physalis Pubescens L.) juice," Journal of Food Processing and Preservation, vol. 34, no. 3, pp. 541-555, 2010. 
[4] A. F. Elsheikha, G. Piombo, T. Goli, and D. Montet, "Main composition of Physalis (Physalis pubescens L.) fruit juice from Egypt,” Fruits, vol. 65, no. 4, pp. 255-265, 2010.

[5] G. Xia, Y. Li, J. Sun et al., "Withanolides from the stems and leaves of Physalis pubescens and their cytotoxic activity," Steroids, vol. 115, pp. 136-146, 2016.

[6] L. Wang, M. Xin, Z. Qin, and H. Liu, "Functional analysis of an iaaM gene in parthenocarpic fruit development in transgenic Physalis pubescens L. plants," Plant Cell, Tissue and Organ Culture, vol. 107, no. 2, pp. 333-340, 2011.

[7] W. Yang, J. Wang, X. Li, and Z. Du, "A new method research for determination of natural pigment crocin yellow in foods by solid-phase extraction ultrahigh pressure liquid chromatography," Journal of Chromatography A, vol. 1218, no. 11, pp. 1423-1428, 2011.

[8] K. Vilkhu, R. Mawson, L. Simons, and D. Bates, "Applications and opportunities for ultrasound assisted extraction in the food industry-a review," Innovative Food Science and Emerging Technologies, vol. 9, no. 2, pp. 161-169, 2008.

[9] E. Espada-Bellido, M. Ferreiro-González, C. Carrera, M. Palma, C. G. Barroso, and G. F. Barbero, "Optimization of the ultrasound-assisted extraction of anthocyanins and total phenolic compounds in mulberry (Morus nigra) pulp," Food chemistry, vol. 219, pp. 23-32, 2017.

[10] A. M. Goula, M. Ververi, A. Adamopoulou, and K. Kaderides, "Green ultrasound-assisted extraction of carotenoids from pomegranate wastes using vegetable oils," Ultrasonics Sonochemistry, vol. 34, pp. 821-830, 2017.

[11] M. C. de Morais Rodrigues, L. L. Borges, F. S. Martins, RH. V. Mourão, and E. C. da Conceição, "Optimization of ultrasound-assisted extraction of phenolic compounds from Myrcia amazonica DC. (Myrtaceae) leaves," Pharmacognosy Magazine, vol. 12, no. 45, p. 9, 2016.

[12] G. Zhang, L. He, and M. Hu, "Optimized ultrasonic-assisted extraction of flavonoids from Prunella vulgaris L. and evaluation of antioxidant activities in vitro," Innovative Food Science and Emerging Technologies, vol. 12, no. 1, pp. 18-25, 2011.

[13] K. H. Wong, G. Q. Li, and K. M. Li, "Optimisation of Pueraria isoflavonoids by response surface methodology using ultrasonic-assisted extraction," Food Chemistry, vol. 231, p. 231, 2017.

[14] J. Deng, Z. Xu, C. Xiang et al., "Comparative evaluation of maceration and ultrasonic-assisted extraction of phenolic compounds from fresh olives," Ultrasonics Sonochemistry, vol. 37, p. 328, 2017.

[15] S. Ferarsa, W. Zhang, N. Moulai-Mostefa, L. H. Ding, M. Y. Jaffrin, and N. Grimi, "Recovery of anthocyanins and other phenolic compounds from purple eggplant peels and pulps using ultrasonic-assisted extraction," Food and Bioproducts Processing, vol. 109, 2018.

[16] A. Pandey, T. Belwal, K. C. Sekar, I. D. Bhatt, and R. S. Rawal, "Optimization of ultrasonic-assisted extraction (UAE) of phenolics and antioxidant compounds from rhizomes of Rheum moorcroftianum, using response surface methodology (RSM)," Industrial Crops and Products, vol. 119, pp. 218-225, 2018.

[17] L. Q. Peng, J. Cao, L. J. Du et al., "Rapid ultrasonic and microwave-assisted micellar extraction of zingiberone, shogaol and gingerols from gingers using biosurfactants," Journal of Chromatography A, vol. 1515, p. 37, 2017.

[18] J. Zhishen, T. Mengcheng, and W. Jianming, "The determination of flavonoid contents in mulberry and their scavenging effects on superoxide radicals," Food Chemistry, vol. 64, no. 4, pp. 555-559, 1999.
[19] P. Wu, G. Ma, N. Li, Q. Deng, Y. Yin, and R. Huang, "Investigation of in vitro and in vivo antioxidant activities of flavonoids rich extract from the berries of Rhodomyrtus tomentosa(Ait.) Hassk," Food Chemistry, vol. 173, pp. 194202, 2015.

[20] Y. J. Li, D. D. Lin, B. Jiao et al., "Purification, antioxidant and hepatoprotective activities of polysaccharide from Cissus pteroclada Hayata," International Journal of Biological Macromolecules, vol. 77, pp. 307-313, 2015.

[21] W. Liu, J. Wang, Z. Zhang et al., "In vitro and in vivo antioxidant activity of a fructan from the roots of Arctium lappa L.," International Journal of Biological Macromolecules, vol. 65, no. 5, pp. 446-453, 2014.

[22] G. Q. Chen, L. Ren, J. Zhang, B. M. Reed, D. Zhang, and X. H. Shen, "Cryopreservation affects ROS-induced oxidative stress and antioxidant response in Arabidopsis seedlings," Cryobiology, vol. 70, no. 1, pp. 38-47, 2015.

[23] P. Zhao, L. Duan, L. Guo et al., "Chemical and biological comparison of the fruit extracts of Citrus wilsonii Tanaka and Citrus medica L.," Food Chemistry, vol. 173, no. 173, pp. 54-60, 2015.

[24] J. P. Maran, B. Priya, and C. V. Nivetha, "Optimization of ultrasound-assisted extraction of natural pigments from Bougainvillea glabra, flowers," Industrial Crops and Products, vol. 63, no. 1, pp. 182-189, 2015.

[25] X. P. Wang, S. X. Dong, and F. Chen, "Ultrasonic-assisted extraction of gardenia yellow from fructus gardeniae," Advanced Materials Research, vol. 396-398, pp. 1075-1078, 2012.

[26] A. Raza, F. Li, X. Xu, and J. Tang, "Optimization of ultrasonicassisted extraction of antioxidant polysaccharides from the stem of Trapa quadrispinosa using response surface methodology," International Journal of Biological Macromolecules, vol. 94, pp. 335-344, 2017.

[27] J. P. Fan, J. Cao, X. H. Zhang et al., "Optimization of ionic liquid based ultrasonic assisted extraction of puerarin from Radix Puerariae Lobatae by response surface methodology," Food Chemistry, vol. 135, no. 4, pp. 2299-2306, 2012.

[28] R. Chaiittianan, P. Chayopas, A. Rattanathongkom, P. Tippayawat, and K. Sutthanut, "Anti-obesity potential of corn silks: relationships of phytochemicals and antioxidation, anti-pre-adipocyte proliferation, anti-adipogenesis, and lipolysis induction," Journal of Functional Foods, vol. 23, pp. 497-510, 2016

[29] L. Kan, S. Nie, J. Hu et al., "Nutrients, phytochemicals and antioxidant activities of 26 kidney bean cultivars," Food and Chemical Toxicology, vol. 108, pp. 467-477, 2016.

[30] V. D. Prá, F. C. Lunelli, R. G. Vendruscolo et al., "Ultrasoundassisted extraction of bioactive compounds from palm pressed fiber with high antioxidant and photoprotective activities," Ultrasonics Sonochemistry, vol. 36, pp. 362-366, 2017.

[31] S. C. Foo, F. M. Yusoff, M. Ismail et al., "Antioxidant capacities of fucoxanthin-producing algae as influenced by their carotenoid and phenolic contents," Journal of Biotechnology, vol. 241, pp. 175-183, 2017. 

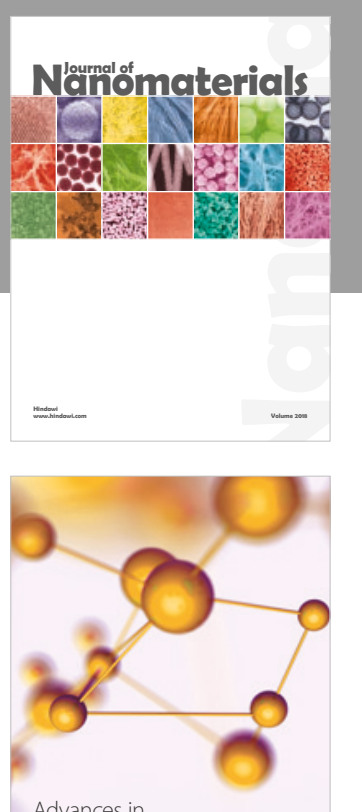

Physical Chemistry
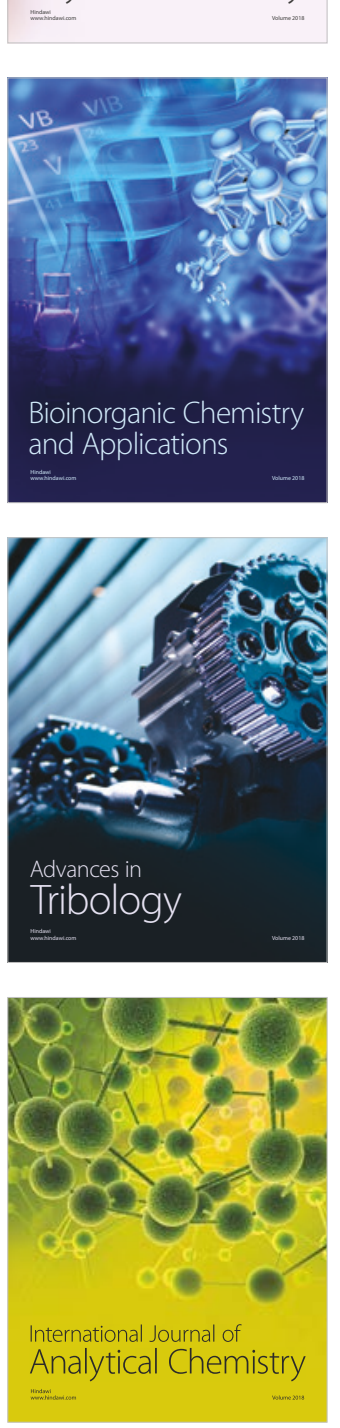

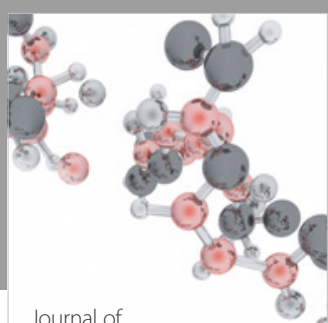

Analytical Methods

in Chemistry

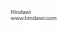

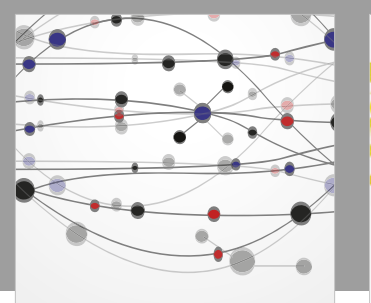

The Scientific World Journal

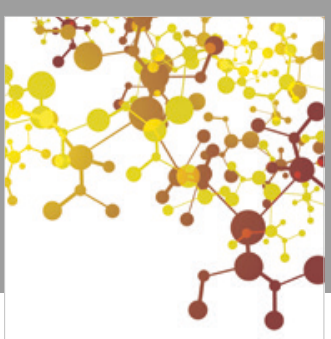

Journal of

Applied Chemistry
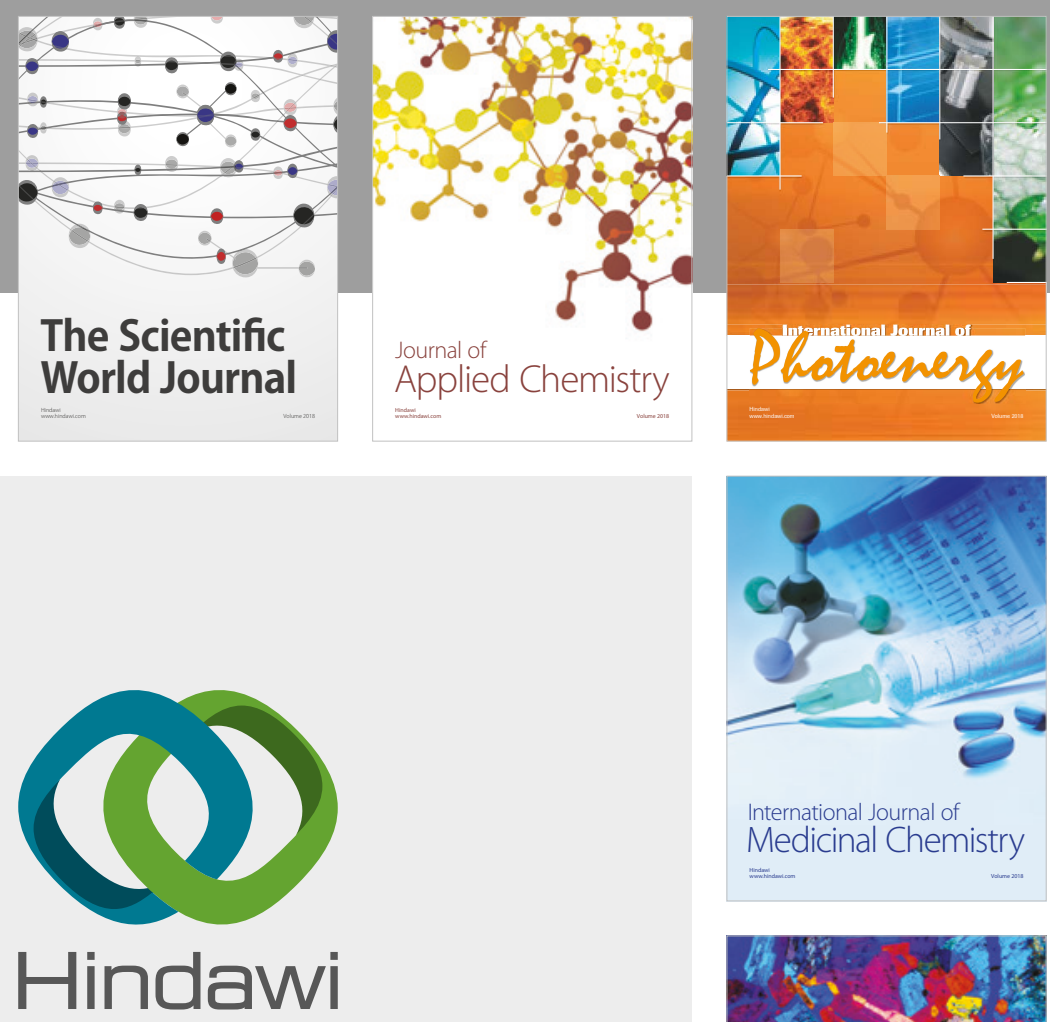

Submit your manuscripts at

www.hindawi.com
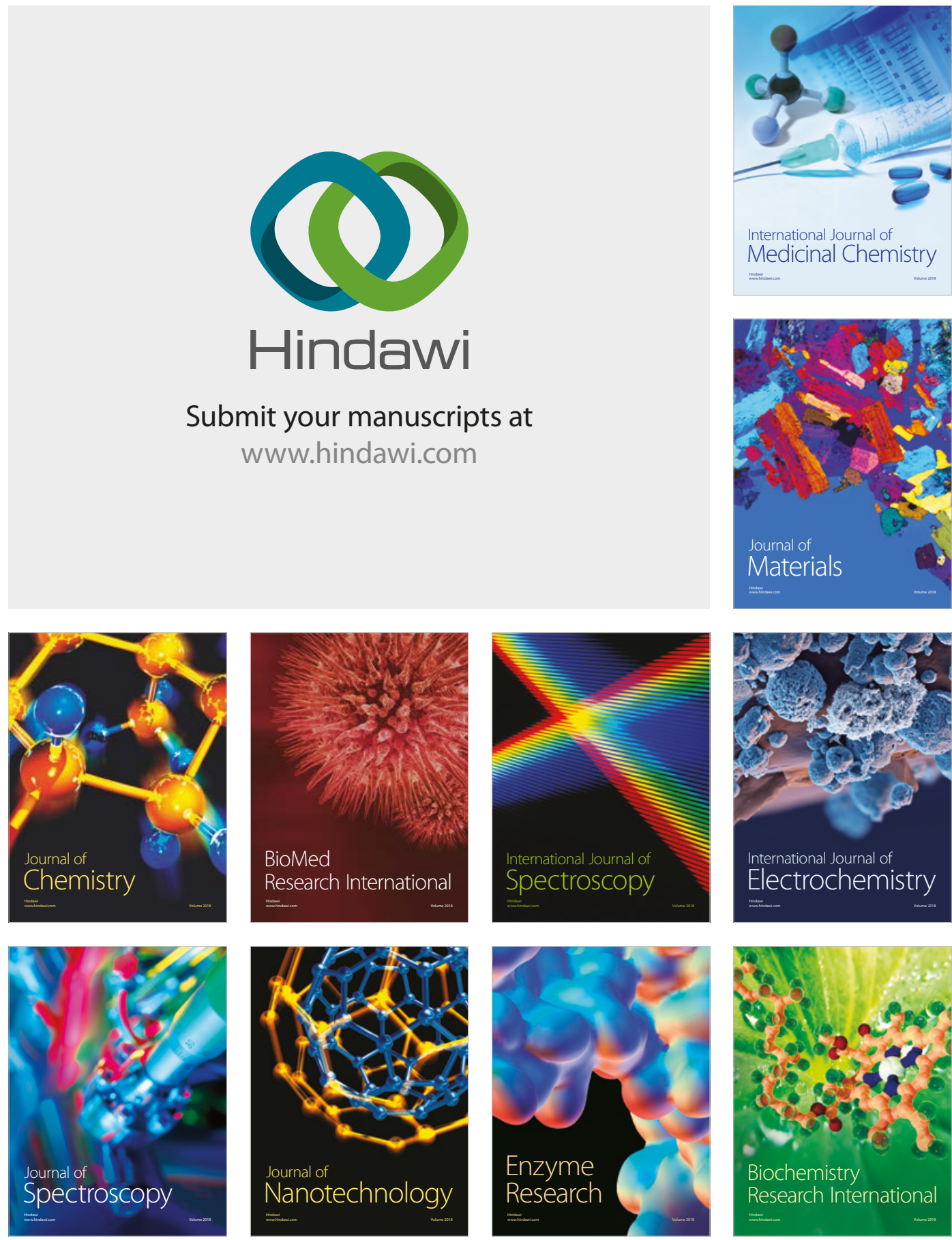
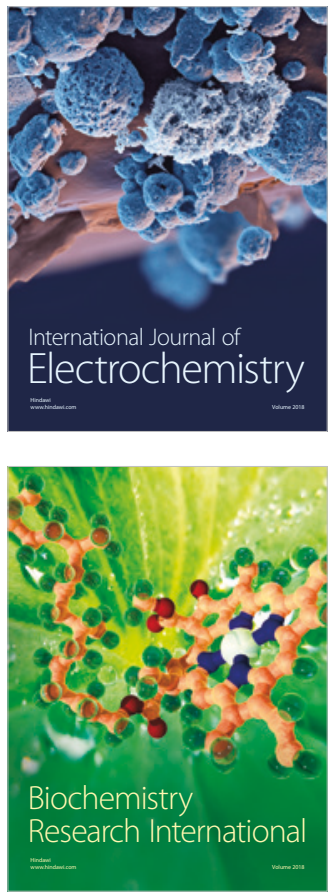